\title{
Sağlık Kurumlarında Çalışan Personelin Yeşil Tedarik Zinciri Hakkında Bilgi Düzeylerinin Belirlenmesi \\ (Determining the Level of Knowledge of the Personnel Working in Health Institutions About Green Supply Chain)
}

\section{E. Asuman ATILlA iD a Furat SEYHAN iD b}

a Ankara Hacı Bayram Veli Üniversitesi, İktisadi ve İdari Bilimler Fakültesi, Ankara, Türkiye. asuman.atilla@hbv.edu.tr

b Sağlık Bilimleri Üniversitesi, Yönetim ve Organizasyon Bölümü, Ankara, Türkiye. firat.seyhan@sbu.edu.tr

\section{MAKALE BİLGİSi \\ Anahtar Kelimeler: \\ Sağlık Kurumları \\ Yeşil Tedarik Zinciri \\ Yeşil Satın Alma \\ Yeşil Üretim \\ Tersine Lojistik}

Gönderilme Tarihi 11

Haziran 2021

Revizyon Tarihi 10

Eylül 2021

Kabul Tarihi 15 Eylül 202

Makale Kategorisi: Araştırma Makalesi

\section{ÖZET}

Amaç - Bu çalışmanın amacı, kaynakların sınırlı, atık depolama ve imha alanlarının yetersiz, tehlikeli madde kullanımı ve atılması ile ilgili personel eğitimlerinin dar kapsamlı ve yenilenebilir enerji kaynakları kullanımı için teşviklerin sınırlı olduğu sağlık işletmelerinde görev yapan personelin yeşil tedarik zinciri hakkında bilgi düzeylerini belirlemektir.

Yöntem - Çalışmanın evrenini Ankara ilinde faaliyet gösteren kamu ve özel sağlık kuruluşlarında görevli çalışanlar oluşturmaktadır. Araştırmada katılımcıların yeşil tedarik zinciri hakkında bilgi düzeylerinin belirlenmesi amacıyla 46 soruluk e-posta yoluyla elektronik anket uygulanmış olup, 296 katılımcı araştırmanın örneklemini oluşturmuştur. Veriler için değişkenlerin miktarını ve türünü belirlemek amacıyla tekil tarama modeli, değişkenler arasındaki ilişkinin varlığını ve değişimin yönünü belirlemek amacıyla da ilişkisel tarama modeli kullanılmıştır. Elde edilen veriler istatistiksel analiz programı ile analiz edilmiş ve yorumlanmıştır.

Bulgular - Yeşil tedarik zinciri yönetimi alt boyutlarının, katılımcıların; cinsiyet, medeni durum, yaş, kurumda çalışma süreleri, sağlık sektöründe çalışma süreleri, görev yaptıkları birimlere göre istatistiksel açıdan farklılık gösterdiği tespit edilmiş olup; katılımcıların gelir düzeyi, meslekleri ve eğitim durumları ile anlamlı farklılık bulunamamıştır.

Tartışma - Çalışmadan elde edilen sonuçlar doğrultusunda, makro düzeyde sağlık sistemi karar verici ve aktörleri mikro düzeyde ise sağlık kurumları yöneticileri ve birim sorumluları tarafından, sağlık kurumlarında çalışan personelin yeşil tedarik zinciri yönetimi ve faaliyetleri hakkında bilinçlendirilmesine yönelik eğitim verilmesinin gerekliliği değerlendirilmekte olup, verilen eğitimler ve yeşil uygulamalar doğrultusunda zincirin tüm paydaşları arasında proaktif bir iletişimin sağlanması ve böylece sağlık kurumlarında çalışan personelin yeşil uygulamalara uyum sağlayıp değişime adapte olabilmeleri açısından önem arz etmektedir.

\section{ARTICLE INFO \\ Keywords: \\ Health Institutions Green Supply Chain Green Purchasing Green Production Reverse Logistics}

Received 11 June 2021 Revised 10 September 2021

Accepted 15 September 2021

Article Classification: Research Article

\section{ABSTRACT}

Purpose - The aim of this study is to determine the level of knowledge of the personnel working in healthcare enterprises about the green supply chain, where resources are limited, waste storage and disposal areas are insufficient, personnel training on the use and disposal of hazardous materials is limited, and incentives for the use of renewable energy resources are limited.

Design/Method/Approach - The population of the study consists of personnel working in public and private health institutions operating in Ankara. In order to determine the knowledge level of the participants about the green supply chain, an online questionnaire with 46 questions was applied and 296 participants formed the sample of the research. For the data, a single scanning model was used to determine the amount and type of variables, and a relational scanning model was used to determine the existence of the relationship between the variables and the direction of the change. The obtained data were analyzed and interpreted with a statistical analysis program.

Findings - Green supply chain management sub-dimensions, participants; It has been determined that there are statistical differences according to gender, marital status, age, working time in the institution, working time in the health sector, and the units they work in; No significant difference was found with the income level, occupation and educational status of the participants.

Discussion - According to the results obtained from the study, it is evaluated that the health system decision makers and actors at the macro level, and the health institutions managers and unit managers at the micro level, the necessity of providing training to raise awareness of the personnel working in health institutions about green supply chain management and activities, and in line with the trainings and green practices. It is important to ensure a proactive communication between all the stakeholders of the chain, and thus the personnel working in health institutions to adapt to green practices and adapt to change. 


\section{Giriş}

Günümüzde işletmeler arasında gerçekleşen rekabet, sadece üretmiş oldukları mal ve hizmetler özelinde değil aynı zamanda üretim sürecinde uyguladıkları tedarik süreçlerindeki stratejiler arasında da gerçekleşmektedir. Dünya genelinde birçok alanda ortaya çıkan gelişmeler işletmelere yeni fırsatlar sunmanın yanı sıra çevreye yönelik bir takım olumsuz yük ve etkileri de beraberinde getirmektedir. İşletmelerin faaliyetlerini gerçekleştirdikleri pazarda ortaya çıkan rekabet, tüketicilerin çevre dostu yeşil ürünlere ve süreçlere yönelik talepleri ve çevreci sivil toplum kuruluşlarının işletmeye yönelik birtakım baskıları işletmeleri, uygulamış oldukları mevcut lojistik stratejilerinde bazı değişiklikler yapmaya yönlendirmiştir. Son dönemlerde atık oranlarında ortaya çıkan büyük artışın yanı sıra, her geçen gün tükenme eğilimi artan hammadde kaynakları işletmeleri çevreye karşı daha duyarlı olmaya yönlendirmiş bu doğrultuda işletmeler hem tedarikçileri ile hem de dağıtım kanalları ile sürdürdükleri ilişkilerinde çevreye karşı daha fazla hassasiyet göstermek durumunda kalmışlardır. Yukarıda bahse konu problemlere karşılık özellikle çevresel kaygıları tedarik zinciri yönetimine entegre eden çevresel bir yenilik olarak Yeşil Tedarik Zinciri Yönetimi ortaya çıkmış ve bu yönetim felsefesi birçok sektörde uygulanmaya başlamıştır. Bu sektörlerden biri olan sağlık hizmetlerinde tedarik zinciri yönetimi diğer sektörlerle kıyaslandığında oldukça kompleks bir yapı söz konusudur. Bunun sebebi ise sağlık hizmetlerinin catering, konaklama, temizlik, hasta taşımacılığı ve çamaşırhane gibi birbirinden farklı ve kendine has nitelikleri olan tamamlayıcı hizmetleri bünyesinde barındırıyor olması ile birlikte bu hizmetlerin ihtiyaç halinde dış kaynak yoluyla temin edilerek sunulmasıdır.

Ülkemiz sağlık sektöründeki yeşil tedarik zinciri yönetimine sağlık çalışanları gözünden bakmayı amaçlayan bu çalışma kapsamında; öncelikle tedarik zinciri yönetimi açıklanmakta, sağlık sektörü özelinde tedarik zinciri yönetimi ve bileşenleri tartışılmakta ve ilerleyen bölümlerde ise yöneticilere ve araştırmacılara rehberlik etmesi amacıyla sağlık sektörü çalışanlarının yeşil tedarik zinciri uygulamaları hakkında bilgi düzeylerini belirlemeye yönelik araştırma kısmı yer almaktadır. Elde edilen bulguların gerek sağlık kurumlarında gerekse diğer sektörlerde yeşil tedarik zinciri literatürüne katkıda bulunmasının yanı sıra uygulamacılara da sağlık kurumlarında yeşil tedarik zinciri uygulamalarında hangi aşamada olunduğunun ve neler yapılması gerektiğinin, bununla birlikte sağlık kurumlarında çalışanların yeşil tedarik zinciri farkındalıklarının ve duyarlılıklarının arttırılmasına yönelik ipuçlarını vermesi açısından katkıda bulunacağı düşünülmektedir.

\section{Kavramsal Çerçeve}

Çalışmanın bu bölümünde; tedarik zinciri, tedarik zinciri yönetimi, yeşil tedarik zinciri, yeşil tedarik zinciri yönetimi kavramları açıklanmış olup yeşil tedarik zinciri yönetimi faaliyetlerinin yanı sıra sağlık işletmelerinde yeşil tedarik zinciri yönetimi kavramları da bu bölümde verilmiştir.

\subsection{Tedarik Zinciri ve Tedarik Zinciri Yönetimi Kavramları}

Tedarik zinciri; tedarikçilerden başlayıp müşterilerde ürün veya hizmet akışı olarak biten bir döngüdür (Bachok vd., 2004:68). Tedarik zinciri aynı zamanda, satıcı, üretici, dağıtııı, perakendecinin müşteri arasındaki bilgi, ürün ve para akışlarının organizasyonunu da kapsar (Veber ve Wallenburg, 2010:16). Tedarik zinciri konusunda çeşitli çalışmalar yapan Lummus ve Alber (Akt. Mishra ve Kumar, 2015:75) ise tedarik zinciri tanımını, malzeme hareketi yolu ile tedarikçiler, dağıtım kanalları, perakendeciler ve müşteriler gibi birçok aktör ve sistemin birleşimi olarak tanımlamaktadır. Lee ve Billington (1992:66)'a göre tedarik zinciri yönetimi hammaddenin temin edilmesiyle başlamakta olup temin edilen hammaddelerin işlenmesi sonucu oluşturulan ürünün dağıtım kanalları vasıtasıyla müşterilere ve nihai tüketicilere ulaştırılması sürecinden meydana gelmektedir. Adeta bir zincir şeklinde işleyen ve zincirin halkaları gibi unsurlarının birbirleriyle yakın ilişki içerisinde olduğu bu sistemin işletmelerde etkin bir şekilde kullanılması büyük önem arz etmekte olup gerek kısa gerek uzun dönemli kararlar alma sürecinde tahminlerin yanı sıra değerlendirilenlerin bilimsel nitelikte yapılabilmesi için bu süreçteki basamaklar doğru bir biçimde tanımlanması ve devamlılı̆̆ının sağlanması oldukça büyük önem arz etmektedir.

\subsection{Yeşil Tedarik Zinciri Kavramı}

Günümüzde işletmeler, çevre konusundaki düzenlemelere bağlı olarak çevresel sorumluluklarının da bilincinde olup, her geçen gün çevreye herhangi bir zarar vermeden süreçlerini devam ettirecek sürdürülebilir sistemlere yönelmektedirler. Hammaddenin temin edilmesinden başlayıp yeniden kullanım veya geri 


\section{E. A. Atilla - F. Seyhan 13/3 (2021) 2488-2506}

dönüşüm veya bertaraf ile biten tedarik zincirinin her aşamasında çevresel sorunlar görülmektedir (Zhu ve Sarkis, 2006:472). Bahse konu sorunlar ve ortaya çıabilecek olan kaynak kıtlı̆̆ sorunu, işletmelerin çevreye duyarlılık konusunda daha bilinçli davranmasına, bununla birlikte işletmelerin yeşil tedarik zinciri yönetimine sahip olma ihtiyacını ortaya çıkarmaktadır. Konu ile ilgili literatür incelendiğinde yeşil tedarik zinciri konusuna yönelik çalışmalar mevcut olup, bunlardan Dheeraj ve Vishal (2012:77), Seman vd. (2012:2) ve Cervera ve Flores (2012:269), Toke vd. (2010:2), Oral (2009:1), Zhu vd. (2008:577), Srivastava (2007:54), Seuring (2004:306) tarafından yeşil tedarik zinciri konusu teorik olarak ele alınmış ve bu doğrultuda yeşil tedarik zinciri kavramı hakkında çeşitli tanımlar yapılmış olup bu tanımlardan bazıları aşağıda verilmiştir.

Yeşil tedarik zinciri, işletmelerin çevresel risk etkilerini azaltarak çevre ve pazar payı hedeflerinin yanı sıra ekolojik verimliliklerini de arttırmalarını ve rekabet avantajını elde etmelerini sağlayan önemli bir yeni modeldir (Zhu ve diğerleri, 2005:451). Yeşil tedarik zinciri, çevresel hususları malzeme yönetimine dahil etmek için tasarlanmış olup bazı durumlarda bir alıcı ile satıcı arasındaki basit bir yeşil satın alma ilişkisi olarak tanımlanırken diğer durumlarda yeşil tedarik zinciri, malzeme ve ürünlerin bitmeyen lojistik döngüsü, kullanımı, yeniden kullanımı ve yönetimini kapsamaktadır (Zhu ve diğerleri, 2008:8). Bu doğrultuda tedarik zinciri yönetimi üzerinde çalışan araştırmacılar, tedarik zincirleri faaliyetlerini, çevresel kavramların önde tutulduğu çevre ile ilgili birtakım hususları da dikkate alarak çalışmalarına yeni bir yön vermişlerdir. Bu konu doğrultuda yeşil tedarik zincirinin yönetilmesi de büyük öneme sahip olup, Cramer (1996:38) yeşil tedarik zincirinin temel hedefinin, zincir boyunca oluşan malzeme döngülerinin sosyal, ekonomik ve çevresel hususlarda duyarlı bir biçimde yürütülmesinin sağlanması şeklinde ifade etmiştir. Yeşil tedarik zinciri yönetimi, çevre dostu işletmelerin tedarik zinciri sürecinde kaynakların bulunması, ürünün oluşturması ve geliştirilmesi, üretimi, dağıtımı, ambalajlanması, depolaması, geri dönüşümü, imha edilmesi, satış sonrası sunulan hizmetler, ürün kullanım ömrü sonunda yönetilmesi gibi süreçlerin birleştirilmesidir (Min ve Kim, 2012:40).

Ho ve diğerleri, (2009:19), yeşil tedarik zinciri ile geleneksel tedarik zinciri arasındaki temel farklılıkları belirlemek amacıyla yapmış oldukları çalışmada konuyu; amaçlar ve değerler, çevresel iyileştirme, tedarikçi seçim kriterleri, maliyet baskısı ve fiyatlar, hız ve esneklik başlıkları altında değerlendirmiş olup temel farklılıklar Tablo 1'de verilmiştir.

Tablo 1. Yeşil Tedarik Zinciri ile Geleneksel Tedarik Zinciri Arasındaki Temel Farklılıklar

\begin{tabular}{|c|c|c|}
\hline Karakteristik & $\begin{array}{c}\text { Geleneksel Tedarik Zinciri } \\
\text { Yönetimi }\end{array}$ & Yeșil Tedarik Zinciri Yönetimi \\
\hline$\underline{\text { Amaçlar ve Değerler }}$ & Ekonomi & Ekonomi ve Çevre \\
\hline$\underline{\text { Cevresel İyileștirme }}$ & Yüksek Çevre Etkisi & $\begin{array}{c}\text { Entegre Yaklaşım, Düşük } \\
\text { Çevresel Etki }\end{array}$ \\
\hline$\underline{\text { Tedarikçi Seçim Kriteri }}$ & $\begin{array}{c}\text { Fiyatlara Bağl1 Tedarikçi } \\
\text { Değiştirme, Kisa Dönemli } \\
\text { İlişkiler }\end{array}$ & $\begin{array}{c}\text { Çevresel Yönler (Artı Fiyat), } \\
\text { Uzun Dönemli İlişkiler }\end{array}$ \\
\hline$\underline{\text { Maliyet Baskısı ve Fiyatlar }}$ & $\begin{array}{c}\text { Yüksek Maliyet Baskısı, Düşük } \\
\text { Fiyatlar }\end{array}$ & $\begin{array}{c}\text { Yüksek Maliyet Baskısı, Yüksek } \\
\text { Fiyatlar }\end{array}$ \\
\hline$\underline{\text { Hiz ve Esneklik }}$ & Yüksek & Düşük \\
\hline
\end{tabular}

Kaynak: Ho ve diğerleri, (2009:19).

Zhu ve Sarkis (2004:265), yapmış oldukları çalışmada, performans ile yeşil tedarik zinciri yönetimi arasında ilişkinin varlığını belirlemek amacıyla Çin' de faaliyet gösteren işletmelerde bir araştırma gerçekleştirmiş olup, bu araştırmada performans göstergeleri ile yeşil tedarik zinciri yönetimi uygulamalarının temel unsurları arasında kuvvetli bir ilişkinin varlığı göstermiştir.

\subsection{Yeşil Tedarik Zinciri Yönetimi}

Özellikle 1990'lı yıllardan itibaren, araştırmacılar ve politika yapıcılar tarafından giderek artan bir şekilde çevre ve iklim değişikliği konusunun yanı sıra her geçen gün daha sık bir biçimde kullanılıp uygulanan yeşil tedarik zinciri konusunda göze çarpan değişikliler yapılmaya başlanmıştır (Walker Sisto ve McBain 2008:69). 


\section{E. A. Atilla - F. Seyhan 13/3 (2021) 2488-2506}

Olumsuz gelişmeler sonucunda işletmeler, çevresel sorunların çözümüne yardımcı olacak, çevre faktörü içeren yönetim stratejilerini benimsemişlerdir. Teknolojik ve uluslararası ticaretteki gelişmeler rekabet koşularında değişmelere ve çevresel problemlere neden olmuştur. Ayrıca işletmeler, organizasyonel performans üzerinde kalıcı bir etki potansiyeli olan ve eksik bir stratejik sorun olan çevre yönetiminin önemli olduğunu fark etmiştir. Bununla birlikte küreselleşme ve ülkelerin dünya ticaret organizasyonuna girişi de yeşil tedarik zinciri uygulamasını teşvik etmiştir.

Zhu ve diğerleri (2007:4333)'ne göre işletmelerde yeşil tedarik zinciri uygulamalarının kullanılmasında, kurumsal baskıların önemli bir rolü bulunmakta kurumsal baskılar; müşteri baskıları, yasal baskılar ve ekonomik baskılardan meydana gelmektedir. Srivastava ve diğerleri (2008:535) ise kurumsal baskıları; küreselleşmenin işletmeler arası rekabeti her geçen gün arttırması, tüketici talep ve beklentilerinin değişmesi (müşteri baskıları), işletme maliyetlerinin azaltılması (ekonomik baskılar), hukuki olarak çevreye yönelik yaptırımların artması (yasal baskılar) işletmelerin faaliyetlerinde yeşil uygulamalar kullanmasına etkili olan baskı unsurları olarak tanımlamıştır.

\subsection{Yeşil Tedarik Zinciri Yönetimi Faaliyetleri}

Yeşil tedarik zinciri faaliyetleri farklılaşmakla birlikte genelde yeşil satın alma, yeşil üretim, yeşil dağıtım ve tersine lojistik olarak sınıflandırılmaktadır. Hervani ve diğerlerine göre yeşil tedarik zinciri yönetimi Şekil 1'de verilmiş olan unsurlardan meydana gelmektedir (Hervani ve diğerleri, 2005:339).

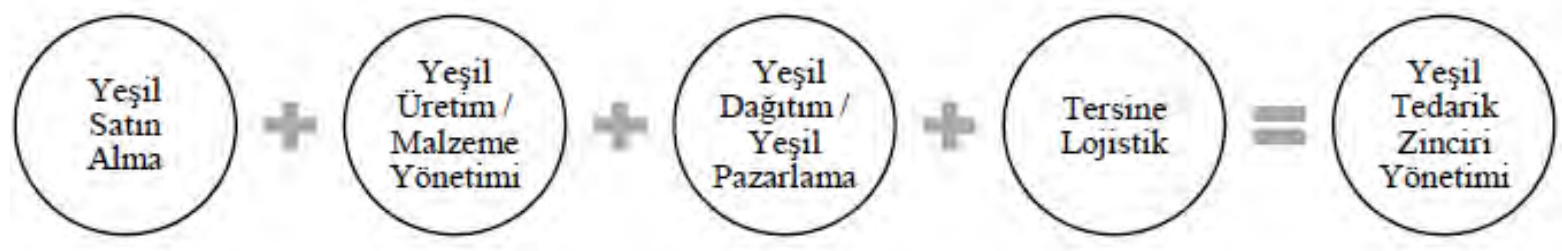

Şekil 1: Yeşil Tedarik Zinciri Yönetimi Unsurları

Öte yandan Dheeraj ve Vishal (2012:78) ise yeşil tedarik zinciri yönetimi faaliyetlerini; yeşil satın alma, yeşil üretim, yeşil pazarlama ve ters lojistik olarak ele almış, Srivastava (2007:61) ise yeşil tedarik zinciri faaliyetlerini Şekil 2'deki gibi sınıflandırmaktadır.

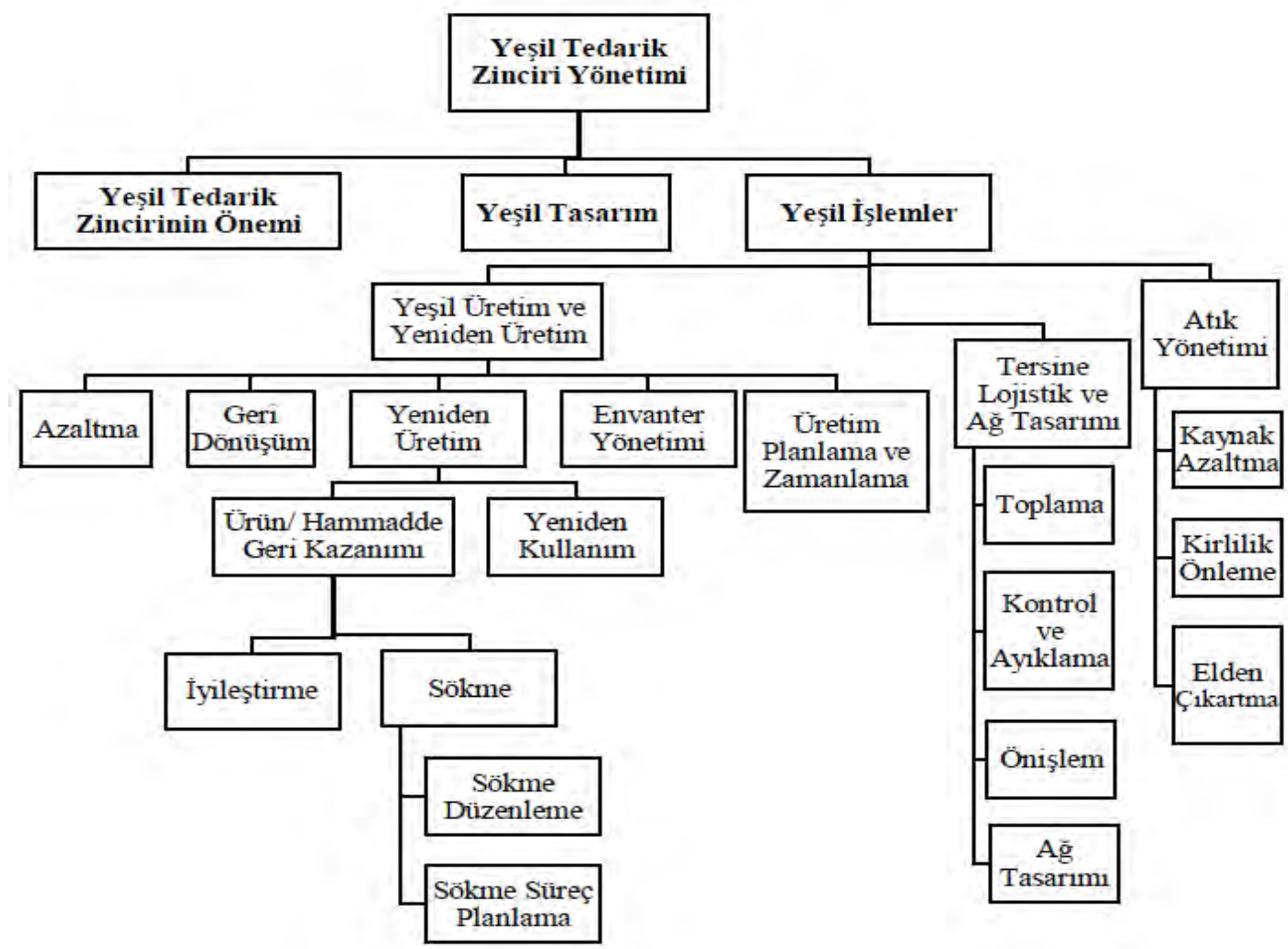

Şekil 2: Yeşil Tedarik Zinciri Yönetiminin Sınıflandırılması 


\section{E. A. Atilla - F. Seyhan 13/3 (2021) 2488-2506}

Görüldügü üzere literatürde yeşil tedarik zinciri yönetimi faaliyetleri, farklı araştırmacılar tarafından çeşitli şekillerde tanımlanmış olsa da genel kabul görmüş yeşil tedarik zinciri yönetimi faaliyetlerini aşağıdaki şekilde sinıflandırmak mümkündür.

Yeşil Satın Alma: Uygun nitelikte talep edilen ürünün doğru zamanda ve yerde, doğru miktarda temin edilmesi amacıyla gerçekleştirilen satın alma faaliyeti, yeşil satın alma özelinde değerlendirildiğinde, tekrar geri dönüşümü sağlanabilecek ve bununla birlikte yeniden kullanıma imkan tanıyan çevreye zarar vermeyen hammadde ve girdilerin temin edilmesi süreci yeşil satın alma olarak tanımlanmaktadır (Büyüközkan ve Vardaloğlu, 2008: 6).

Yeşil Üretim ve Malzeme Yönetimi: Yeşil üretim ile ilgili Büyüközkan ve Vardaloğlu (2008:8) tarafından yapılmış olan tanımda, üretim aşamasında gerçekleştirilen süreçlerinin ve bu aşamalarda kullanılan teknolojilerin, ortaya çıkan atıkları veya zararlı unsurları ortadan kaldıracak şekilde tasarımı, geliştirilip uygulamaya konulması şeklinde ifade edilmiştir. Shamdasani ve diğerleri (1993:490) tarafından yapılmış olan bir başka tanımda ise yeşil üretim, çevreyi kirletmeyen veya üretim sürecinde kullanılan doğal kaynakların tüketimine neden olmayan ve geri dönüşümünü sağlayabilen ya da mevcut durumunu koruyabilen üretim süreci olarak tanımlanmıştır.

Yeşil Dağıtım ve Pazarlama: Günümüzde müşterilerin çevre dostu ürünlere talebi artarken bu süreçte işletme yöneticilerinin üretimini gerçekleştirmiş olduğu ürün yelpazelerini inceleyerek müşteri talep ve beklentilerine göre gereken değişim ve yenilikleri gerçekleştirmesi büyük önem arz etmektedir. Bu bağlamda yeşil dağıtım ve yeşil pazarlama faaliyetlerinin çok iyi bir biçimde belirlenerek yeşil kavramına uygun bir şekilde çevre dostu unsurlarla desteklenip güçlendirilerek tasarlanması ve işletmenin kar maksimizasyonunu sağlamaya yönelik olarak dizaynı da büyük önem arz etmektedir.

Yeşil Paketleme: Yapılan paketleme faaliyetleri, yeşil tedarik zinciri yönetiminde işletmenin ve aynı zamanda ürünün performansını önemli ölçüde etkilemekte olup, iyi bir biçimde tasarlanmış olan paketler, dağıtım aşamasında ürünlerin zarar verici dış etmenlerden korunmasının yanı sıra iyi bir biçimde tasarlanmış ürün paketlemesi sayesinde depolama, taşıma ve dağıtım süreçlerinde hacim olarak daha çok yerin kullanılmasıyla daha fazla ürün ile faaliyetlerin gerçekleştirilmesini sağlamaktadır. Yeşil tedarik zinciri yönetimi kapsamında yukarıda bahse konu hususlar dikkate alınarak çevreye duyarlı ve zarar vermeyecek bir şekilde ürünlerin paketlenmesinin yapılması için, paketlerin şekil ve boyutunun yanı sıra, paketleme aşamasında çevreye duyarlı malzemelerin kullanılmasına özen gösterilmelidir.

Yeşil Tersine Lojistik: Tersine lojistik faaliyetleri, kaynak israfının önüne geçmek amacıyla yeniden kullanım, geri dönüşüm ya da bertaraf edilmesi yoluyla daha önce kullanılmış olan ürünlerin, ayrıştırılmak üzere toplanması, gerçekleştirilen bazı süreçlerden sonra tekrar kullanılmak üzere dağıtılması olarak tanımlanmaktadır (Büyüközkan ve Vardaloğlu, 2008:8). İleri yönlü lojistikte tedarik edilen girdilerle yeni bir ürünün ya da malın üretiminden bahsedilebilirken tersine lojistikte ise daha öncesinde kullanılmış olan ürünlerin ayrıştırılmak üzere toplanması, geri dönüşüm süreci, geri kazanım amacıyla yeniden üretilmesi ve bunların tekrar dağıtımı gibi çeşitli süreçler ortaya çıkmaktadır.

\subsection{Sağlık İşletmelerinde Yeşil Tedarik Zinciri Yönetimi}

Günümüzde, sağlık hizmetlerinde sürekli değişen teknolojik ve ekonomik koşullar ile birlikte artan yoğun rekabet ortamı, işletmelerin mevcut pazarda varlıklarını sürdürebilmek için daha hızlı, daha girişimci ve daha yenilikçi olmasını gerektirmektedir. Bugün, sağlık hizmetlerinin en önemli alt sistemleri arasında olan hastaneler, yönetimi oldukça zor olan en karmaşık organizasyonlar arasında sayılmaktadır (Kaitelidou ve diğerleri, 2012:571). Günümüzde oldukça hızlı bir şekilde değişim ve gelişim gösteren sağlık hizmetlerinin amaçlarından birisi hastalıkların ortadan kaldırılması olup bu amacı yerine getirirken de çevreye zarar vermeyen uygulamalara azami oranda önem vermesini gerektirmektedir.

Yapay zekâ, nesnelerin interneti, 3D yazıcılar, sanal gerçeklik, otomasyon ve robot teknolojilerinin hüküm sürdüğü ve iş süreçlerini kolaylaştırıp yeni fırsatlar sunduğu günümüz sağlık hizmetlerinin diğer hizmetlerden farklı özelliklerinden kaynaklanan hemen hemen hepsinin hayati öneme haiz olduğu ürünlerin, istenilen zamanda, istenilen yerde ve tam ihtiyaç duyulan miktarda hazır halde bulunması amaciyla gerçekleştirilen bütün çalışmalar tedarik zinciri yönetiminin fonksiyonudur. Sağlık kurumları yönetiminin önemli fonksiyonlarından birisi de hastaların tanı ve tedavi sürecinde kullanılan malzemelerin ihtiyaçlarının 


\section{E. A. Atilla - F. Seyhan 13/3 (2021) 2488-2506}

belirlenmesi faaliyetlerinin zamanında ve iyi koşullarda gerçekleştirilmesi, bahse konu malzemelerin ihtiyaç duyulan bölüme ihtiyaç duyulan zaman zarfında ulaştırılmasının sağlanması ve bütün bu hizmetlerin faturalandırılması sağlanmasıdır (Tengilimoğlu, Işık ve Akbolat, 2009).

Tengilimoğlu ve Yiğit (2017:24) yapmış oldukları sağlık hizmetlerinde tedarik zinciri yönetimini; kullanılan malzemenin hammadde kaynağından en son tüketiciye yani hastaya ulaşıncaya kadar geçen süreçte, üreticiler, dağıtıcılar, perakendeciler, hizmet sunucu ve sağlayıcıların yanı sıra hastalardan oluşan tüm paydaşların birbirleri ile uyumlu bir biçimde hareket etmesini sağlamak amacıyla malların, hizmetlerin ve bilginin akışını yöneten bütünleşik bir sistem olarak tanımlanmaktadır.

Sağlık hizmetlerinde sürekli değişen teknolojik ve ekonomik koşullar ile birlikte artan yoğun rekabet ortamı, işletmelerin mevcut pazarda varlıklarını sürdürebilmek için daha hızlı, daha girişimci ve daha yenilikçi olmasını gerektirmekte, bu yaşamsal öneme sahip olan gereklilikleri yerine getirmek için de faaliyette bulunduğu çevresel unsurlara önem vererek çevre ile ilgili sorumlulukları yerine getirip, çevreye herhangi bir zarar vermeden süreçlerini devam ettirecek sürdürülebilir sistemlere sahip olmayı gerektirmektedir. Ancak sınırlı kaynakların olduğu, tıbbi atıkların hem depolama hem de imha alanlarının yetersiz kaldı $\breve{g} ı$, tıbbi gazlar ve birtakım kimyasal tehlikeli maddelerin yaygın şekilde kullanıldı ̆̆ı, ilgili personel eğitimlerinin dar kapsamlı olduğu ve bununla birlikte yenilenebilir enerji kaynakları kullanımı için teşviklerin sınırlı olduğu sağlık işletmelerinde yeşil tedarik kavramının gündeme gelmesiyle, yeşil tedarik zincirinin doğru bir şekilde kurularak sağlık kurumlarında etkili ve verimli bir biçimde kullanılabilmesi için bahse konu sağlık kurumları yöneticilerine büyük bir görev düşmektedir. Bu doğrultuda sağlık kurumlarında tedarik zinciri süreçlerine etki eden çok sayıda faktör bulunmakta olup bu faktörlerden bazılarını; sağlık çalışanlarının tedarik zinciri yönetimi konusundaki bilgi seviyeleri, kullanılan demirbaş, tıbbi cihaz, sarf malzemeleri ve ilaçların çeşitlilik göstermesi, hukuki ve yasal konular (patent sorunları, tıbbi malzeme ve ilaç tedarikçileri arasındaki mevcut rekabet düzeyleri vb.), üst yönetim kademesinin tedarik zinciri faaliyetlerine destek düzeyi, tedarik zincirindeki iş süreçlerinin koordinasyonu hususu" gibi unsurlardır (Bhakoo ve Chan 2011:185).

Sağllk sektöründe yeşil tedarik zinciri yönetimi konusunda ilgili literatür incelendiğinde; Terekli ve diğerleri (2013) tarafından sağlık sektöründe yeşil hastane faaliyetlerinin uygulanabilirlik düzeyini belirlemenin yanı sıra hem çevreye hem de sağlık kurumlarına sağladığı faydaları tespit etmek amacıyla gerçekleştirilen çalışmada, gerek kamu gerekse de özel hastanelerde görev yapan kurum yöneticilerine, çevre dostu yeşil stratejilerin uygulanması ve buna yönelik yaklaşımların benimsenmesini ve çevre dostu yenilenebilir enerji kaynaklarının kullanımının teşvik edilmesini önermişlerdir.

\section{Yöntem}

Bu bölümde; çalışma kapsamında test edilecek hipotezler, çalışmanın gerçekleştirildiği evren ve örneklem, kullanılan veri toplama aracı ve toplanan verilerin analizinin hakkında bilgi verilmektedir.

\subsection{Hipotezler}

Hı: Katılımcıların cinsiyet durumuna göre yeşil tedarik zinciri yönetimi alt boyutlarına ilişkin görüşlerinde farklılık bulunmaktadır.

$\mathrm{H}_{2}$ : Katılımcların medeni durumlarına göre yeşil tedarik zinciri yönetimi alt boyutlarına ilişkin görüşlerinde farklılık bulunmaktadır.

$\mathrm{H}_{3}$ : Katılımcıların yaşına göre yeşil tedarik zinciri yönetimi alt boyutlarına ilişkin görüşlerinde farklılık bulunmaktadır.

$\mathrm{H}_{4}$ : Katılımcıların gelir düzeyine göre yeşil tedarik zinciri yönetimi alt boyutlarına ilişkin görüşlerinde farklılık bulunmaktadır.

$\mathrm{H}_{5}$ : Katılımcların mesleklerine göre yeşil tedarik zinciri yönetimi alt boyutlarına ilişkin görüşlerinde farklılık bulunmaktadır.

H6: Katılımcıların eğitim durumlarına göre yeşil tedarik zinciri yönetimi alt boyutlarına ilişkin görüşlerinde farklılık bulunmaktadır.

H7: Katılımcların kurumda çalışma süresine göre yeşil tedarik zinciri yönetimi alt boyutlarına ilişkin görüşlerinde farklılık bulunmaktadır. 


\section{E. A. Atilla - F. Seyhan 13/3 (2021) 2488-2506}

$\mathrm{H}_{8}$ : Katılımcıların sağlık sektöründe çalışma süresine göre yeşil tedarik zinciri yönetimi alt boyutlarına ilişkin görüşlerinde farklılık bulunmaktadır.

H9: Katılımcıların çalıştıkları Klinik/Bölüm/Birime göre yeşil tedarik zinciri yönetimi alt boyutlarına ilişkin görüşlerinde farklılık bulunmaktadır.

\subsection{Evren ve Örneklem}

Araştırmanın evrenini Ankara ilinde hizmet sunmakta olan bir kamu hastanesi oluşturmakta olup, bahse konu hastaneden alınan güncel veriler doğrultusunda araştırmanın başladığı tarih itibari ile hastanede toplam 2053 personel görev yapmaktadır. Araştırmada, hastanede görev yapan personelin tamamı ile görüşmek yerine, örnekleme yöntemiyle bir kısmı ile görüşülmesinin uygun olacağına karar verilmiş olup bu doğrultuda aşağıdaki oransal örneklem hacmi formülünden faydalanılmıştır (Newbold, 1995:867).

$$
n=\frac{N p(1-p)}{(N-1) \sigma_{p_{x}}^{2}+p(1-p)}
$$

Burada; n: örnek hacmi, N: popülasyon hacmi (2053), P: tahmin oranını, olasılık düzeyi güven aralığını (\%90 güven aralığı, 0.05 hata payı için 1.645 s 0.05 eşitliğinden s: 0.0039) ifade etmektedir (Newbold, 1995:867). Araştırmada maksimum örnek hacmine ulaşılmak istenmiş olup bu amaçla p: 0.50 ve $(1-p)$ : 0.50 alınmıştır. Formüle göre $\% 90$ güven düzeyinde ve $\% 5$ hata payı ile ulaşılması gereken örneklem sayısı $n=240$ olarak hesaplanmıştır. Verilerin toplanması aşamasında ana kütlenin tamamını incelemek, zaman ve maliyet bakımından mümkün olmadığından çalışma, kartopu örnekleme yöntemi ile ve çalışmaya katılmaya gönüllü olan toplam 296 çalışana çevrimiçi soru formuna ilişkin bağlantı linki gönderilerek gerçekleştirilmiştir.

\subsection{Veri Toplama Arace}

Araştırmanın verileri elde etmek amacıyla anket tekniğinden yararlanılmıştır. Anket formu olarak kullanılan ölçek, daha önceki araştırmalarda kullanılmış, yüksek güvenirlik ve geçerlilik sergilemiş bir ölçek olup, verileri elde etmek amacıyla iki bölümden oluşan anket uygulanmıştır. Anketin birinci bölümünde; cinsiyet, medeni durum, yaş, eğitim düzeyi, meslek, gelir düzeyi ve sağlık sektöründe çalışma süresine ilişkin demografik özellikleri belirlemeye yönelik 9 soru; ikinci bölümde ise Korucuk (2018) tarafından sağlık işletmelerinin yeşil lojistik uygulama düzeyleri ve yeşil lojistik uygulamalarının sağlık işletmelerinde rekabet etme gücü ve hastane performansına etkisini belirlemeye yönelik yapmış olduğu çalışmasında kullanmış olduğu ölçeğe yer verilmiştir. Ölçekte; yeşil tedarik, yeşil üretim ve malzeme yönetimi, yeşil paketleme, yeşil taşıma, yeşil depolama, yeşil tersine lojistik faaliyetleri olmak üzere beş alt boyuttan oluşan ve sağlık kurumlarında çalışan personelin yeşil tedarik zinciri hakkında bilgi düzeylerini ölçmeyi amaçlayan 37 soru bulunmaktadır. Kullanılan ölçek, "Kesinlikle Katılmıyorum" ile "Kesinlikle Katılıyorum" arasında değer alan 5'li likert tipinde bir ölçektir. Çalışmanın etik yönden uygunluk izni 26.02.2021 tarihinde Ankara Hacı Bayram Veli Üniversitesi Etik Komisyonu'ndan alınmış olup, veriler 29.02.2021- 30.03.2021 tarihleri arasında gerçekleştirilmiştir. Kartopu örnekleme yöntemi ile ulaşılabilen kişilere, veri toplama aracında; cevapların araştırmanın amacı dışında kullanılmayacağı ve katılımın gönüllülük esasına dayandığı, çalışmaya katılan hiç kimseden kimlik bilgilerinin istenmediği ifade edilmiş olup çalışmaya katılmaya gönüllü olan kişilere çevrimiçi soru formuna ilişkin bağlantı linki gönderilmiştir.

\subsection{Verilerin Analizi}

Elektronik posta aracılığıyla uygulanan anket sonucu elde edilen veriler SPSS programı ile analiz edilmiştir. Analiz sonucu veriler normal dağılım gösterdiğinden $(\mathrm{p}>0.05)$ parametrik testler uygulanmıştır. Araştırmada öncelikle katılımcıların demografik özelliklerini belirlemek amacıyla frekans dağılımları alınmıştır. Demografik değişkenler ile ilişkiyi belirlemek amacıyla Bağımsız Örneklemlerde T Testi ve Tek Yönlü Varyans Analizi (Anova) yapılmıştır. Değişkenler arasındaki ilişkinin varlığını ve değişimin yönünü belirlemek amacıyla da Korelasyon analizi yapılmıştır.

\section{Bulgular}

Araştırmadan elde edilen bulgular bu bölümde yer almakta olup katılımcılara ait tanımlayıcı bulgular, araştırmada kullanılan ölçeklerin geçerlilik ve güvenilirlik analizlerine ilişkin bulguların yanı sıra boyutlara yönelik yapılan analizlere ilişkin bulgular da bu bölümde verilmiştir. 
E. A. Atilla - F. Seyhan 13/3 (2021) 2488-2506

\subsection{Güvenilirlik Analizine İlişkin Bulgular}

Tablo 2. Güvenilirlik Analizine İlişkin Bulgular

\begin{tabular}{|c|c|c|}
\hline Boyutlar & Cronbach' Alpha & İfade say1s \\
\hline Yeşil Tedarik & 0,89 & 7 \\
\hline Yeşil Üretim ve Malzeme Yönetimi & 0,88 & 6 \\
\hline Yeşil Paketleme & 0,88 & 6 \\
\hline Yeşil Taşıma & 0,89 & 6 \\
\hline Yeşil Depolama & 0,84 & 7 \\
\hline Yeşil Tersine Lojistik & 0,85 & 5 \\
\hline
\end{tabular}

Ölçeklerde yer alan ifadelerin aynı yapıyı ölçüp ölçmediği, diğer bir ifade ile kendi içerisinde tutarlı bir ilişki içerisinde olup olmadığını belirlemek amacıyla yapılan güvenilirlik analizi sonuçları Tablo 2'de verilmiştir. Kullanılan ölçek için güvenilirlik analizi ilk olarak her boyut için ayrı ayrı uygulanmıştır. Çünkü Cronbach Alfa değeri örneklem ve ifade sayısı ile birlikte yükselme eğilimi gösterdiğinden bütünden çok faktör düzeyindeki sonuçlar daha hassas görülmektedir (Yaşlığlu, 2017). Buna göre her bir ölçeğe ilişkin Cronbach Alfa katsayısı sosyal bilimler için geçerli olan 0,70'in üzerindedir ve ölçeğin güvenilir olduğu görülmektedir.

\subsection{Değişkenlerin Analizine İlişkin Bulgular}

Tablo 3. Tek Boyutluluk Analizine İlişkin Bulgular

\begin{tabular}{|c|c|}
\hline Boyut & Faktör Yükü \\
\hline \multicolumn{2}{|l|}{ Yeşil Tedarik } \\
\hline Tedarik1 & 670 \\
\hline Tedarik2 & ,761 \\
\hline Tedarik3 & 857 \\
\hline Tedarik4 & ,730 \\
\hline Tedarik5 & 829 \\
\hline Tedarik6 & ,796 \\
\hline \multirow[t]{2}{*}{ Tedarik7 } & ,743 \\
\hline & KMO:,860 \\
\hline \multicolumn{2}{|c|}{ Yeşil Üretim ve Malzeme Yönetimi } \\
\hline Üretim1 & 862 \\
\hline Üretim2 & 740 \\
\hline Üretim3 & 657 \\
\hline Üretim4 & 615 \\
\hline Üretim5 &, 509 \\
\hline Üretim6 & 663 \\
\hline \multicolumn{2}{|c|}{ KMO:,817 } \\
\hline \multicolumn{2}{|c|}{ Yeşil Paketleme } \\
\hline Paketleme1 & 779 \\
\hline Paketleme2 & 821 \\
\hline Paketleme3 & 787 \\
\hline Paketleme4 & 818 \\
\hline Paketleme5 & 792 \\
\hline Paketleme6 & ,724 \\
\hline \multicolumn{2}{|c|}{ KMO: ,874 } \\
\hline \multicolumn{2}{|l|}{ Yeşil Taşıma } \\
\hline Taşıma1 & 639 \\
\hline
\end{tabular}


E. A. Atilla - F. Seyhan 13/3 (2021) 2488-2506

\begin{tabular}{|c|c|}
\hline Taşıma2 & ,765 \\
\hline Taşıma3 & 787 \\
\hline Taşıma4 & ,750 \\
\hline Taşıma5 & ,858 \\
\hline Taşıma6 & 797 \\
\hline \multicolumn{2}{|c|}{ KMO:,867 } \\
\hline \multicolumn{2}{|c|}{ Yeşil Depolama } \\
\hline Depolama1 & ,648 \\
\hline Depolama2 & ,734 \\
\hline Depolama3 & ,747 \\
\hline Depolama4 & 696 \\
\hline Depolama5 & 753 \\
\hline Depolama6 & ,758 \\
\hline Depolama7 & 671 \\
\hline \multicolumn{2}{|c|}{ KMO:,782 } \\
\hline \multicolumn{2}{|c|}{ Yeşil Tersine Lojistik } \\
\hline Lojistik1 & 674 \\
\hline Lojistik2 & 866 \\
\hline Lojistik3 & 833 \\
\hline Lojistik4 & 826 \\
\hline Lojistik5 & ,752 \\
\hline \multicolumn{2}{|c|}{ KMO:,799 } \\
\hline
\end{tabular}

Tablo 3'e göre; ifadelerin, bulunduğu boyutu temsil edip etmediğini belirlemek amacıyla yapılan tek boyutluluk analizi sonucunda her boyutun altında yer alan ifadelerin faktör yükleri 0,40 üzerinde olduğundan herhangi bir ifade çıkarılmamıştır. Aynı zamanda örneklem büyüklüğünün yeterliliğini gösteren KMO katsayısı da her boyut için 0,70 'in üzerindedir.

Tablo 4. Boyutlara İlişkin Ortalamalar

\begin{tabular}{|c|c|c|}
\hline Boyutlar & $\overline{\boldsymbol{X}}$ & s.s \\
\hline Yeşil Tedarik & 3,2780 & 69683 \\
\hline Yeşil Üretim ve Malzeme Yönetimi & 3,3705 & 67870 \\
\hline Yeşil Paketleme & 3,2466 & 65103 \\
\hline Yeşil Taşıma & 3,2095 & 71352 \\
\hline Yeşil Depolama & 3,1969 & 62357 \\
\hline Yeşil Tersine Lojistik & 3,4486 & 67355 \\
\hline
\end{tabular}

Ölçek boyutlarına ilişkin otalamaların verildiği Tablo 4 incelendiğinde, ortalamaların birbirine yakın değerlerde olduğu görülmektedir. Ancak yeşil tersine lojistik ile yeşil üretim ve malzeme yönetimi ortalamalarının diğer boyutlara nazaran yüksek olduğu görülmektedir $(3,4486 ; 3,3705)$.

\subsection{Katılımcıların Sosyo-Demografik Özellikleri ve Çalışmanın Genel Bulguları}

Bu bölümde araştırmaya katılan katılımcıların cinsiyet, yaş, medeni durum, gelir durumu, meslek, öğrenim durumu, bulundukları kurumda çalışma süresi, sağlık sektöründe çalışma süresi ve çalışılan klinik/bölüm/birim değişkenlerine ait oransal ve sayısal dağılımlara yer verilmiştir. 
E. A. Atilla - F. Seyhan 13/3 (2021) 2488-2506

Tablo 5. Katılımcıların Sosyo-Demografik Özelliklerine Yönelik Bulgular (n=296)

\begin{tabular}{|c|c|c|c|}
\hline Değişkenler & & Frekans & Yüzde \\
\hline \multirow{2}{*}{ Cinsiyet } & Kadın & 134 & 45,3 \\
\hline & Erkek & 162 & 54,7 \\
\hline \multirow{4}{*}{ Yaş } & 25 yaş ve altı & 64 & 21,6 \\
\hline & 26-34 arası & 90 & 30,4 \\
\hline & $35-41$ arası & 94 & 31,8 \\
\hline & 42 ve üzeri & 48 & 16,2 \\
\hline \multirow{2}{*}{ Medeni durum } & Evli & 194 & 65,5 \\
\hline & Bekâr & 102 & 34,5 \\
\hline \multirow{4}{*}{ Gelir Durumu } & $2000-4000$ & 46 & 15,5 \\
\hline & $4001-6000$ & 96 & 32,4 \\
\hline & $6001-8000$ & 126 & 42,6 \\
\hline & 8001 ve üzeri & 28 & 9,5 \\
\hline \multirow{4}{*}{ Meslek } & Doktor & 24 & 8,1 \\
\hline & Hemşire & 74 & 25 \\
\hline & Hasta Danışmanı & 32 & 10,8 \\
\hline & Yardımcı Personel & 166 & 56,1 \\
\hline \multirow{3}{*}{ Öğrenim durumu } & Ön lisans & 102 & 34,5 \\
\hline & Lisans & 134 & 45,3 \\
\hline & Lisansüstü & 60 & 20,3 \\
\hline \multirow{4}{*}{ Bulundukları kurumda çalışma süresi } & 1 y1l ve alt1 & 40 & 13,5 \\
\hline & 2-8 yıl arası & 136 & 45,9 \\
\hline & 9-15 y1l arası & 76 & 25,7 \\
\hline & 16 yıl ve üzeri & 44 & 14,9 \\
\hline \multirow{4}{*}{ Sağlık sektöründe çalışma süresi } & 3 yil ve alt1 & 58 & 19,6 \\
\hline & 4-11 y1l arası & 106 & 35,8 \\
\hline & $12-19$ yıl arası & 74 & 25 \\
\hline & 20 yıl ve üzeri & 58 & 19,6 \\
\hline \multirow{5}{*}{ Klinik/Bölüm/ Birim } & Poliklinik & 114 & 38,5 \\
\hline & Laboratuvar & 26 & 8,8 \\
\hline & Radyoloji & 78 & 26,4 \\
\hline & İdari Birim & 48 & 16,2 \\
\hline & Ameliyathane-yoğun bakım & 30 & 10,1 \\
\hline
\end{tabular}

Katılımcıların sosyo-demografik özelliklerine göre dağılımları Tablo 5'te görülmektedir. Katılımcıların 134'ü $(\% 45,3)$ kadın ve 162'si (\%54,7) erkektir. Katılımcıların yaş dağılımları incelendiğinde, 64 kişinin $(\% 21,6) 25$ yaş ve altı yaş aralığında, 90 kişinin (\%30,4) 26-34 yaş aralığında, 94 kişinin $(\% 31,8)$ 35-41 yaş aralığında ve 48 kişinin $(\% 16,2) 42$ ve üzeri yaş aralığında olduğu bulunmuştur. Katılımcıların medeni durumları incelendiğinde, 194' ünün (\%65,5) evli, 102'sinin ise (\%34,5) bekâr olduğu tespit edilmiştir. Katılımclların gelir durumları incelendiğinde 23'ünün (\%15,5) 2000-4000 TL arası, 48'inin (\%32,4) 4001-6000 TL arası, 126'sının 6001-8000 TL arası ve $28^{\prime}$ inin 8001 TL ve üzeri gelir durumuna sahip olduğu bulunmuştur. Katılımciların meslekleri değerlendirildiğinde $24^{\prime}$ ünün $(\% 8,1)$ hekim, $74^{\prime}$ ünün $(\% 25)$ hemşire, 32'sinin $(\% 10,8)$ hasta danışmanı ve 166 'sının (\%56,1) yardımcı sağlık hizmetleri personeli olduğu bulunmuştur. Katılımcıların öğrenim durumları incelendiğinde 102'sinin $(\% 34,5)$ ön lisans mezunu, 134'ünün $(\% 45,3)$ lisans mezunu ve $60^{\prime} ı$ ın $(\% 20,3)$ lisansüstü düzeyinde öğrenim durumuna sahip olduğu tespit edilmiştir. Katılımcıların bu 


\section{E. A. Atilla - F. Seyhan 13/3 (2021) 2488-2506}

kurumda çalışma sürelerine bakıldığında, 40'ı (\%13,5) 1 yıl ve daha az, 136'sı (\%45,9) 2-8 yıl, 76'sı (\%25,7) 915 yıl ve $44^{\prime} \ddot{u}(\% 14,9) 16$ yıl ve üzeri bu kurumda çalışma süresine sahip oldukları görülmektedir. Katılımcıların sağlık sektöründe çalışma sürelerine bakıldığında, 58'i $(\% 19,6) 3$ yıl ve daha az, 106'sı (\%35,8) 4-11 yıl, 74'ü (\%25) 12-19 yıl ve 58'i (\%19,6) 20 yıl ve üzeri sağlık sektöründe çalışma süresine sahip oldukları görülmektedir. Katılımcıların çalıştıkları klinik/bölüm/birim vs. incelendiğinde, 114'ünün $(\% 38,5)$ polikliniklerde, $26^{\prime}$ sinın $(\% 8,8)$ laboratuvarda, $78^{\prime}$ inin $(\% 26,4)$ radyolojide, $48^{\prime}$ inin $(\% 16,2)$ idari birimlerde ve 30 'unun $(\% 10,1)$ ameliyathane/yoğun bakımda çalıştığı belirlenmiştir.

Tablo 6. Cinsiyete Göre Fark Analiz Sonuçları

\begin{tabular}{|c|c|c|c|c|c|c|}
\hline & Cinsiyet & $\mathbf{n}$ & Ortalama & $\begin{array}{c}\text { Std. } \\
\text { Sapma }\end{array}$ & $\mathbf{t}$ & $\mathbf{p}$ \\
\hline \multirow[t]{2}{*}{ Yeşil Tedarik } & Kadın & 134 & 3,2260 & 69859 & \multirow[b]{2}{*}{,- 824} & \multirow{2}{*}{,41 } \\
\hline & Erkek & 162 & 3,3210 & 69676 & & \\
\hline \multirow[t]{2}{*}{ Yeşil Üretim ve Malzeme Yönetimi } & Kadın & 134 & 3,3010 & 63248 & \multirow{2}{*}{$-1,134$} & \multirow{2}{*}{,25 } \\
\hline & Erkek & 162 & 3,4280 & ,71343 & & \\
\hline \multirow[t]{2}{*}{ Yeşil Paketleme } & Kadın & 134 & 3,2388 & 61218 & \multirow{2}{*}{,- 132} & \multirow{2}{*}{, 89} \\
\hline & Erkek & 162 & 3,2531 & 68522 & & \\
\hline \multirow[t]{2}{*}{ Yeşil Taşıma } & Kadın & 134 & 3,2090 & 70074 & \multirow{2}{*}{,- 008} & \multirow{2}{*}{,99 } \\
\hline & Erkek & 162 & 3,2099 & 72829 & & \\
\hline \multirow[t]{2}{*}{ Yeşil Depolama } & Kadın & 134 & 3,2111 & ,57861 & \multirow{2}{*}{,251 } & \multirow{2}{*}{, 80} \\
\hline & Erkek & 162 & 3,1852 & 66180 & & \\
\hline \multirow[t]{2}{*}{ Yeşil Tersine Lojistik } & Kadın & 134 & 3,3134 & 63744 & \multirow{2}{*}{$-2,252$} & \multirow{2}{*}{,02 } \\
\hline & Erkek & 162 & 3,5605 & ,68587 & & \\
\hline
\end{tabular}

Katılımcıların cinsiyet durumuna göre Yeşil Tedarik Zinciri Yönetimi alt boyutlarına ilişkin farklılık olup olmadığı bağımsız örneklerde $t$ testi ile analiz edilmiş, Tablo 6 'da görüldüğü üzere yeşil tedarik zinciri yönetiminin alt boyutlarından sadece yeşil tersine lojistik ile cinsiyet arasında istatistiksel olarak anlamlı farklılık görülmektedir $(\mathrm{p}<0,05)$. Buna göre ortalamalar incelendiğinde erkek katılımcıların ortalamasının kadınlara göre daha yüksek olduğu tespit edilmiştir.

Tablo 7. Medeni Duruma Göre Fark Analiz Sonuçları

\begin{tabular}{|c|c|c|c|c|c|c|}
\hline & Cinsiyet & $\mathbf{n}$ & Ortalama & $\begin{array}{c}\text { Std. } \\
\text { Sapma }\end{array}$ & $\mathbf{t}$ & $\mathbf{p}$ \\
\hline \multirow[b]{2}{*}{ Yeşil Tedarik } & Evli & 194 & 3,2371 & 67885 & \multirow[b]{2}{*}{,- 984} & \multirow[b]{2}{*}{,32 } \\
\hline & Bekar & 102 & 3,3557 & 73032 & & \\
\hline \multirow{2}{*}{ Yeşil Üretim ve Malzeme Yönetimi } & Evli & 194 & 3,3007 & 63857 & \multirow{2}{*}{$-1,738$} & \multirow{2}{*}{,08 } \\
\hline & Bekar & 102 & 3,5033 & 73748 & & \\
\hline \multirow{2}{*}{ Yeşil Paketleme } & Evli & 194 & 3,2251 & 66451 & \multirow{2}{*}{,- 554} & \multirow{2}{*}{,58 } \\
\hline & Bekar & 102 & 3,2876 & ,62900 & & \\
\hline \multirow{2}{*}{ Yeşil Taşıma } & Evli & 194 & 3,1942 & 69417 & \multirow{2}{*}{,- 359} & \multirow{2}{*}{,72 } \\
\hline & Bekar & 102 & 3,2386 & 75517 & & \\
\hline \multirow{2}{*}{ Yeşil Depolama } & Evli & 194 & 3,1414 & ,59992 & \multirow{2}{*}{$-1,500$} & \multirow{2}{*}{ 13 } \\
\hline & Bekar & 102 & 3,3025 & 65940 & & \\
\hline \multirow{2}{*}{ Yeşil Tersine Lojistik } & Evli & 194 & 3,3485 & 65465 & \multirow{2}{*}{$-2,542$} & \multirow{2}{*}{,01 } \\
\hline & Bekar & 102 & 3,6392 & 67412 & & \\
\hline
\end{tabular}

Katılımcıların medeni durumlarına göre Yeşil Tedarik Zinciri Yönetimi alt boyutlarına ilişkin farklılık olup olmadığı bağımsız örneklerde $t$ testi ile analiz edilmiş, Tablo 7 'de görüldüğü üzere yeşil tedarik zinciri yönetiminin alt boyutlarından sadece yeşil tersine lojistik ile medeni durum arasında istatistiksel olarak anlamlı farklılık görülmektedir $(\mathrm{p}<0,05)$. Buna göre ortalamalar incelendiğinde bekar katılımcıların ortalamasının evli olanlara göre daha yüksek olduğu tespit edilmiştir. 
E. A. Atilla - F. Seyhan 13/3 (2021) 2488-2506

Tablo 8. Yaş Gruplarına Göre Fark Analiz Sonuçları

\begin{tabular}{|c|c|c|c|c|c|c|c|}
\hline & Yaş Grubu & $\mathbf{n}$ & Ortalama & $\begin{array}{c}\text { Std. } \\
\text { Sapma }\end{array}$ & $\mathbf{F}$ & $\mathbf{p}$ & $\begin{array}{l}\text { Post } \\
\text { Hoc }\end{array}$ \\
\hline \multirow{4}{*}{ Yeşil Tedarik } & 25 yaş ve altı & 64 & 3,5402 & 0,68534 & \multirow{4}{*}{3,422} & \multirow{4}{*}{0,01} & \multirow{4}{*}{$\begin{array}{l}1>3 \\
1>4\end{array}$} \\
\hline & $26-34$ arasi & 90 & 3,3683 & 0,60109 & & & \\
\hline & 35-41 aras1 & 94 & 3,1033 & 0,68816 & & & \\
\hline & 42 ve üzeri & 48 & 3,1012 & 0,7909 & & & \\
\hline \multirow{4}{*}{ Yeşil Üretim ve Malzeme Yönetimi } & 25 yaş ve altı & 64 & 3,5729 & 0,71208 & \multirow{4}{*}{2,332} & \multirow{4}{*}{0,07} & \multirow{4}{*}{ - } \\
\hline & 26-34 arasi & 90 & 3,4519 & 0,62827 & & & \\
\hline & $35-41$ aras1 & 94 & 3,2518 & 0,65189 & & & \\
\hline & 42 ve üzeri & 48 & 3,1806 & 0,7205 & & & \\
\hline \multirow{4}{*}{ Yeşil Paketleme } & 25 yaş ve altı & 64 & 3,5365 & 0,59978 & \multirow{4}{*}{3,785} & \multirow{4}{*}{0,01} & \multirow{4}{*}{$\begin{array}{l}1>3 \\
1>4\end{array}$} \\
\hline & $26-34$ aras1 & 90 & 3,2889 & 0,47194 & & & \\
\hline & $35-41$ aras1 & 94 & 3,1028 & 0,72777 & & & \\
\hline & 42 ve üzeri & 48 & 3,0625 & 0,73526 & & & \\
\hline \multirow{4}{*}{ Yeşil Taşıma } & 25 yaş ve altı & 64 & 3,5000 & 0,62073 & \multirow{4}{*}{3,825} & \multirow{4}{*}{0,01} & \multirow{4}{*}{$\begin{array}{l}1>3 \\
1>4 \\
2>4\end{array}$} \\
\hline & $26-34$ aras1 & 90 & 3,2704 & 0,63593 & & & \\
\hline & 35-41 aras1 & 94 & 3,1064 & 0,75295 & & & \\
\hline & 42 ve üzeri & 48 & 2,9097 & 0,7661 & & & \\
\hline \multirow{4}{*}{ Yeşil Depolama } & 25 yaş ve altı & 64 & 3,4375 & 0,647 & \multirow{4}{*}{4,308} & \multirow{4}{*}{0,00} & $1>3$ \\
\hline & $26-34$ aras1 & 90 & 3,3048 & 0,56785 & & & $1>4$ \\
\hline & 35-41 aras1 & 94 & 3,0486 & 0,58545 & & & $2>3$ \\
\hline & 42 ve üzeri & 48 & 2,9643 & 0,64337 & & & $2>4$ \\
\hline \multirow{4}{*}{ Yeşil Tersine Lojistik } & 25 yaş ve altı & 64 & 3,7875 & 0,61369 & \multirow{4}{*}{3,687} & \multirow{4}{*}{0,01} & \multirow{4}{*}{$\begin{array}{l}1>2 \\
1>3 \\
1>4\end{array}$} \\
\hline & 26-34 aras1 & 90 & 3,3733 & 0,62755 & & & \\
\hline & $35-41$ arası & 94 & 3,3617 & 0,65227 & & & \\
\hline & 42 ve üzeri & 48 & 3,3083 & 0,7621 & & & \\
\hline
\end{tabular}

$\mathbf{1}=25$ yaş ve altı; $\mathbf{2}=26-34$ yaş; $\mathbf{3}=35-41$ yaş; $\mathbf{4}=42$ yaş ve üzeri

Katılımcıların yaşına göre yeşil tedarik zinciri yönetimi alt boyutlarına ilişkin farklılık olup olmadığı tek yönlü varyans analizi (Anova) kullanılarak analiz edilmiş, Tablo 8' de görüldüğü üzere yeşil tedarik zinciri yönetimi alt boyutlarından yeşil üretim ve malzeme yönetimi boyutu dışındaki tüm alt grupların, yaş gruplarına göre istatistiksel açıdan farklılık gösterdiği tespit edilmiştir $(\mathrm{p}<0,05)$. Ortaya çıkan bu farkın hangi yaş gruplarından kaynaklandığının tespit edilmesi için yapılan Post Hoc testi sonucuna göre farklılığın yeşil tedarik için 25 yaş ve altı yaş grubu ile 35-41 yaş arası ve 42 yaş ve üzeri grup arasından kaynaklandığı ve 25 yaş ve altı yaş grubunun diğer gruplara göre daha yüksek bir ortalamaya sahip olduğu bulunmuştur.

Katılımcıların gelir düzeyine göre yeşil tedarik zinciri yönetimi alt boyutlarına ilişkin istatistiksel olarak anlamlı farklılık bulunup bulunmadığını belirlemek amacıyla yapılan analiz sonucunda anlamlı farklılık görülmemiştir ( $p>0,05)$.

Katılımcıların mesleklerine göre yeşil tedarik zinciri yönetimi alt boyutlarına ilişkin istatistiksel olarak anlamlı farklılık bulunup bulunmadığını belirlemek amacıyla yapılan analiz sonucunda anlamlı farklılık görülmemiştir ( $>00,05)$.

Katılımcıların eğitim durumlarına göre yeşil tedarik zinciri yönetimi alt boyutlarına ilişkin istatistiksel olarak anlamlı farklılık bulunup bulunmadığını belirlemek amacıyla yapılan analiz sonucunda anlamlı farklılık görülmemiştir ( $p>0,05)$. 
E. A. Atilla - F. Seyhan 13/3 (2021) 2488-2506

Tablo 9. Kurumda Çalışma Süresine Göre Fark Analiz Sonuçları

\begin{tabular}{|c|c|c|c|c|c|c|c|}
\hline & $\begin{array}{c}\text { Kurumda } \\
\text { Çalışma } \\
\text { Süresi }\end{array}$ & $\mathbf{n}$ & Ortalama & $\begin{array}{c}\text { Std. } \\
\text { Sapma }\end{array}$ & $\mathbf{F}$ & p & $\begin{array}{l}\text { Post } \\
\text { Hoc }\end{array}$ \\
\hline \multirow{4}{*}{ Yeşil Tedarik } & 1 yıl ve altı & 40 & 3,3857 & 0,69384 & \multirow{4}{*}{6,37} & \multirow{4}{*}{0,00} & \multirow{4}{*}{$\begin{array}{l}4<1 \\
4<2 \\
4<3\end{array}$} \\
\hline & 2-8 yıl arası & 136 & 3,4475 & 0,6853 & & & \\
\hline & 9-15 yıl arası & 76 & 3,2218 & 0,56238 & & & \\
\hline & $\begin{array}{c}16 \text { yıl ve } \\
\text { üzeri }\end{array}$ & 44 & 2,7532 & 0,71385 & & & \\
\hline \multirow{4}{*}{$\begin{array}{l}\text { Yeşil Üretim ve Malzeme } \\
\text { Yönetimi }\end{array}$} & 1 yıl ve altı & 40 & 3,5 & 0,73747 & \multirow{4}{*}{5,498} & \multirow{4}{*}{0,00} & \multirow{4}{*}{$\begin{array}{l}4<1 \\
4<2 \\
4<3\end{array}$} \\
\hline & 2-8 yıl arası & 136 & 3,5074 & 0,62853 & & & \\
\hline & 9-15 yıl arası & 76 & 3,3421 & 0,61628 & & & \\
\hline & $\begin{array}{c}16 \text { yıl ve } \\
\text { üzeri }\end{array}$ & 44 & 2,8788 & 0,68657 & & & \\
\hline \multirow{4}{*}{ Yeşil Paketleme } & 1 yıl ve altı & 40 & 3,3583 & 0,64272 & \multirow{4}{*}{7,132} & \multirow{4}{*}{0,00} & \multirow{4}{*}{$\begin{array}{l}4<1 \\
4<2 \\
4<3\end{array}$} \\
\hline & 2-8 yıl arası & 136 & 3,3873 & 0,57695 & & & \\
\hline & 9-15 yıl arası & 76 & 3,25 & 0,57703 & & & \\
\hline & $\begin{array}{l}16 \text { yıl ve } \\
\text { üzeri }\end{array}$ & 44 & 2,7045 & 0,74878 & & & \\
\hline \multirow{4}{*}{ Yeşil Taşıma } & 1 yıl ve alt1 & 40 & 3,375 & 0,74118 & \multirow{4}{*}{2,505} & \multirow{4}{*}{0,06} & \multirow{4}{*}{-} \\
\hline & 2-8 yıl arası & 136 & 3,299 & 0,62927 & & & \\
\hline & 9-15 yıl arası & 76 & 3,1579 & 0,65982 & & & \\
\hline & $\begin{array}{c}16 \text { yıl ve } \\
\text { üzeri }\end{array}$ & 44 & 2,8712 & 0,92715 & & & \\
\hline \multirow{4}{*}{ Yeşil Depolama } & 1 yıl ve altı & 40 & 3,3714 & 0,56841 & \multirow{4}{*}{2,656} & \multirow{4}{*}{0,05} & \multirow{4}{*}{$\begin{array}{l}4<1 \\
4<2\end{array}$} \\
\hline & $2-8$ yıl arası & 136 & 3,2878 & 0,63385 & & & \\
\hline & 9-15 yıl arası & 76 & 3,0865 & 0,47385 & & & \\
\hline & $\begin{array}{c}16 \text { yıl ve } \\
\text { üzeri }\end{array}$ & 44 & 2,9481 & 0,78065 & & & \\
\hline \multirow{4}{*}{ Yeşil Tersine Lojistik } & 1 yıl ve altı & 40 & 3,48 & 0,71789 & \multirow{4}{*}{3,694} & \multirow{4}{*}{0,01} & \multirow{4}{*}{$\begin{array}{l}2>3 \\
2>4\end{array}$} \\
\hline & 2-8 yıl arası & 136 & 3,6176 & 0,65812 & & & \\
\hline & 9-15 yıl arası & 76 & 3,3053 & 0,60043 & & & \\
\hline & $\begin{array}{c}16 \text { yıl ve } \\
\text { üzeri }\end{array}$ & 44 & 3,1455 & 0,68224 & & & \\
\hline
\end{tabular}

$\mathbf{1 =} 1$ yıl ve altı; $2=2-8$ yıl arası; $3=9-15$ yıl arası; $4=16$ yıl ve üzeri

Katılımcıların kurumda çalışma süresine göre yeşil tedarik zinciri yönetimi alt boyutlarına ilişkin farklılık olup olmadığı tek yönlü varyans analizi (Anova) kullanılarak analiz edilmiş, Tablo 9'da görüldüğü üzere yeşil tedarik zinciri yönetimi alt boyutlarından yeşil taşıma haricinde yeşil tedarik ile diğer alt grupların, kurumda çalışma süreleri gruplarına göre istatistiksel açıdan farklılık gösterdiği tespit edilmiştir $(\mathrm{p}<0,05)$. Ortaya çıan bu farkın hangi gruplarından kaynaklandığının tespit edilmesi için yapılan Post Hoc testi sonucuna göre farklılığın yeşil tedarik için 16 yıl ve üzeri çalışan ile 1 yıl ve altı, 2-8 yıl arası ve 9-15 yıl arası çalışanlardan kaynaklandığ1 ve 16 yıl ve üzeri çalışan grubunun diğer gruplara göre daha düşük bir ortalamaya sahip olduğu bulunmuştur. Yeşil üretim alt boyutu için 16 yıl ve üzeri çalışan ile 1 yıl ve altı, 2-8 yıl arası ve 9-15 yıl arası çalışanlardan kaynaklandığı ve 16 yıl ve üzeri çalışan grubunun diğer gruplara göre daha düşük bir ortalamaya sahip olduğu bulunmuştur. Yeşil paketleme alt boyutu için 16 yıl ve üzeri çalışan ile 1 yıl ve altı, 


\section{E. A. Atilla - F. Seyhan 13/3 (2021) 2488-2506}

2-8 yıl arası ve 9-15 yıl arası çalışanlardan kaynaklandığı ve 16 yıl ve üzeri çalışan grubunun diğer gruplara göre daha düşük bir ortalamaya sahip olduğu bulunmuştur. Yeşil depolama alt boyutu için 16 yıl ve üzeri çalışan ile 1 yıl ve altı, 2-8 yıl arasından kaynaklandığı ve 16 yıl ve üzeri çalışan grubunun diğer gruplara göre daha düşük bir ortalamaya sahip olduğu bulunmuştur. Yeşil tersine lojistik alt boyutu için 2-8 yıl arası ile 915 yıl arası ve 16 yıl ve üzeri çalışan grup arasından kaynaklandığı, 2-8 yıl arası grubunun diğer gruplara göre daha yüksek bir ortalamaya sahip olduğu tespit edilmiştir.

Tablo 10. Sağlık Sektöründe Çalışma Süresine Göre Fark Analiz Sonuçları

\begin{tabular}{|c|c|c|c|c|c|c|c|}
\hline & $\begin{array}{c}\text { Sağlık } \\
\text { Sektöründe } \\
\text { Çalışma Süresi }\end{array}$ & $\mathbf{n}$ & Ortalama & $\begin{array}{l}\text { Std. } \\
\text { Sapma }\end{array}$ & $\mathbf{F}$ & p & Post Hoc \\
\hline \multirow{4}{*}{ Yeşil Tedarik } & 3 yil ve alt1 & 58 & 3,4778 & 0,76196 & \multirow{4}{*}{3,414} & \multirow{4}{*}{0,01} & \multirow{4}{*}{$\begin{array}{l}1>3 \\
2>4\end{array}$} \\
\hline & 4-11 yil arası & 106 & 3,4151 & 0,6178 & & & \\
\hline & $12-19$ y1l arası & 74 & 3,0772 & 0,62777 & & & \\
\hline & 20 y1l ve üzeri & 58 & 3,0837 & 0,7641 & & & \\
\hline \multirow{4}{*}{$\begin{array}{l}\text { Yeşil Üretim ve } \\
\text { Malzeme Yönetimi }\end{array}$} & 3 yıl ve altı & 58 & 3,569 & 0,83276 & \multirow{4}{*}{2,393} & \multirow{4}{*}{0,07} & \multirow{4}{*}{ - } \\
\hline & 4-11 y1l arası & 106 & 3,4591 & 0,58003 & & & \\
\hline & $12-19$ y1l arası & 74 & 3,2162 & 0,61847 & & & \\
\hline & 20 yıl ve üzeri & 58 & 3,2069 & 0,7024 & & & \\
\hline \multirow{4}{*}{ Yeşil Paketleme } & 3 yil ve alt1 & 58 & 3,477 & 0,6512 & \multirow{4}{*}{4,13} & \multirow{4}{*}{0,00} & \multirow{4}{*}{$\begin{array}{l}1>2 \\
1>4 \\
2>4\end{array}$} \\
\hline & 4-11 yil arası & 106 & 3,3459 & 0,56882 & & & \\
\hline & $12-19$ y1l arası & 74 & 3,1577 & 0,59957 & & & \\
\hline & 20 y1l ve üzeri & 58 & 2,9483 & 0,74948 & & & \\
\hline \multirow{4}{*}{ Yeşil Taşıma } & 3 yil ve alt1 & 58 & 3,4598 & 0,7024 & \multirow{4}{*}{3,328} & \multirow{4}{*}{0,02} & \multirow{4}{*}{$\begin{array}{c}1>2 \\
1>4 \\
2>4\end{array}$} \\
\hline & 4-11 y1l arası & 106 & 3,3082 & 0,62395 & & & \\
\hline & $12-19$ y1l arası & 74 & 3,0631 & 0,67512 & & & \\
\hline & 20 y1l ve üzeri & 58 & 2,9655 & 0,83497 & & & \\
\hline \multirow{4}{*}{ Yeşil Depolama } & 3 yil ve altı & 58 & 3,2857 & 0,71429 & \multirow{4}{*}{4,11} & \multirow{4}{*}{0,00} & \multirow{4}{*}{$\begin{array}{l}2>3 \\
2>4\end{array}$} \\
\hline & 4-11 yıl arası & 106 & 3,3854 & 0,56977 & & & \\
\hline & $12-19$ y1l arası & 74 & 3,0116 & 0,52205 & & & \\
\hline & 20 y1l ve üzeri & 58 & 3 & 0,64569 & & & \\
\hline \multirow{4}{*}{ Yeşil Tersine Lojistik } & 3 yıl ve altı & 58 & 3,6345 & 0,75037 & \multirow{4}{*}{1,411} & \multirow{4}{*}{0,24} & \multirow{4}{*}{ - } \\
\hline & 4-11 yıl arası & 106 & 3,4792 & 0,58748 & & & \\
\hline & $12-19$ y1l arası & 74 & 3,3784 & 0,65453 & & & \\
\hline & 20 yıl ve üzeri & 58 & 3,2966 & 0,74761 & & & \\
\hline
\end{tabular}

1= 3 yıl ve altı; $2=4-11$ yıl arası; $3=12-19$ yıl arası; $4=20$ yıl ve üzeri

Katılımcıların sağlık sektöründe çalışma süresine göre yeşil tedarik zinciri yönetimi alt boyutlarına ilişkin farklılık olup olmadığ tek yönlü varyans analizi (One Way Anova) kullanılarak analiz edilmiş, Tablo 10'da görüldügü üzere yeşil tedarik zinciri yönetimi alt boyutlarından yeşil tedarik, yeşil paketleme, yeşil taşıma ve yeşil depolama boyutlarında istatistiksel açıdan anlamlı farklılık görülmüştür $(p<0,05)$. Ortaya çıkan bu farkın hangi yaş gruplarından kaynaklandığının tespit edilmesi için yapılan Post Hoc testi sonucuna göre farklılığın yeşil tedarik alt boyutu için 3 yıl ve altı ile 12-19 yıl arası ve 20 yıl ve üzeri çalışanlardan kaynaklandığ ve 3 yıl ve altı çalışanların daha yüksek ortalamaya sahip olduğu ve 4-11 yıl arası ile 12-19 yıl arası çalışanlardan kaynaklandığı ve 4-11 yıl arası çalışanların daha yüksek bir ortalamaya sahip olduğu bulunmuştur. Yeşil paketleme alt boyutu için 3 yıl ve altı ile 12-19 yıl arası ve 20 yıl ve üzeri çalışanlardan kaynaklandığ 1 ve 3 yıl ve altı çalışanların daha yüksek ortalamaya sahip olduğu ve 4-11 yıl arası ile 20 yıl ve üzeri çalışanlardan kaynaklandığı ve 4-11 yıl arası çalışanların daha yüksek bir ortalamaya sahip olduğu bulunmuştur. Yeşil taşıma alt boyutu için 3 yıl ve altı ile 12-19 yıl arası ve 20 yıl ve üzeri çalışanlardan kaynaklandığı ve 3 yıl ve 


\section{E. A. Atilla - F. Seyhan 13/3 (2021) 2488-2506}

altı çalışanların daha yüksek ortalamaya sahip olduğu ve 4-11 yıl arası ile 4-11 yıl arası ile 20 yıl ve üzeri çalışanlardan kaynaklandığı ve 4-11 yıl arası çalışanların daha yüksek bir ortalamaya sahip olduğu bulunmuştur. Yeşil depolama alt boyutu için 4-11 yıl arası ile 12-19 yıl arası ve 20 yıl ve üzeri çalışanlardan kaynaklandığı ve 4-11 yıl arası çalışanların daha yüksek ortalamaya sahip olduğu bulunmuştur.

Tablo 11. Klinik/Bölüm/Birim Göre Fark Analiz Sonuçları

\begin{tabular}{cccccccc}
\hline & Klinik/Bölüm/Birim & n & Ortalama & Std. Sapma & F & p & Post Hoc \\
\hline \multirow{4}{*}{ Üretim } & Poliklinik & 114 & 3,2573 & 0,76251 & & & \\
& Laboratuvar & 26 & 3,2949 & 0,61295 & & & \\
& Radyoloji & 78 & 3,2778 & 0,57651 & 2,549 & 0,042 & $4>1$ \\
& İdari Birim & 48 & 3,7153 & 0,60688 & & & \\
& Ameliyathane-yoğun & & & & & & \\
bakım & 30 & 3,5556 & 0,59982 & & & \\
\hline
\end{tabular}

1= Poliklinik; 2=Laboratuvar; 3= Radyoloji; 4= İdari Birim; 5= Ameliyathane-Yoğun bakım

Katılımcıların çalıştıkları Klinik/Bölüm/Birime göre yeşil tedarik zinciri yönetimi alt boyutlarına ilişkin farklılık olup olmadığı tek yönlü varyans analizi (One Way Anova) kullanılarak analiz edilmiş, Tablo 11'de görüldügü üzere yeşil tedarik zinciri yönetimi alt boyutlarından yeşil üretim ve malzeme yönetimi boyutunda istatistiksel açıdan anlamlı farklılık görülmüştür $(\mathrm{p}<0,05)$. Ortaya çıkan bu farkın hangi gruptan kaynaklandığının tespit edilmesi için yapılan Post Hoc testi sonucuna göre farklılığın idari birim çalışanları ile poliklinik çalışanları ve radyoloji çalışanları arasından kaynaklandığı ve idari birimde çalışanların diğer gruplardan daha yüksek olduğu bulunmuştur.

\section{Sonuç ve Tartışma}

Son yıllarda yaşanan ve tüm sektörleri etkisi altına alan yoğun ve hızlı teknolojik dönüşüm, sadece sektörel anlamda değil; politik, ekonomik ve uluslararası çevrenin yanı sıra işletmelerin organizasyonel yapısını da doğrudan ya da dolaylı şekilde etkilemektedir. Ancak teknolojideki bu hızlı gelişmelerin yanı sıra işletmelerin sergiledikleri yoğun üretim süreci, beraberinde çevre kirliliğini ve doğanın aşırı bir biçimde tahrip edilmesini de getirmektedir. Küreselleşmenin, rekabetin ve değişimin tedarik zincirine damgasını vurduğu bu dönemde atık oranlarında ortaya çıkan büyük artışın yanı sıra; kurumsal baskılar, müşteri baskıları, yasal baskılar ve ekonomik baskılarla birlikte her geçen gün tükenme eğilimi artan hammadde kaynakları, işletmeleri çevreye karşı daha duyarlı olmaya yönlendirmiş bu doğrultuda işletmeler de hem tedarikçileri hem de dağıtım kanalları ile sürdürdükleri ilişkilerinde çevreye karşı daha fazla hassasiyet göstermek durumunda kalmışlardır. Bu bağlamda yeşil tedarik zinciri yönetimi, işletmeler tarafından çevreye duyarlılık anlayışının benimsenmesi ve bahse konu bu unsurların gündeme alınıp uygulamaya geçirilmesi hususunda kilit bir role sahiptir.

Söz konusu değişim ve gelişimin en yoğun şekilde yaşandığı sektörlerden biri olan sağlık hizmetlerinin amaçlarından biri de, hastalıkların ortadan kaldırılmasıdır. Ancak, bu amacı yerine getirirken de çevreye zarar vermeyen uygulamalara azami oranda yer verilmesi büyük önem arz etmektedir. Çünkü bir sağllk işletmesinin sunmuş olduğu hizmetlerin üretiminden nihai kullanıcı tarafından tüketilinceye kadarki süreçte benimseyeceği yeşil tedarik zinciri yönetimi anlayışı, sağlık hizmetleri tüketicilerinin çevreci taleplerini karşılayarak hem mevcut pazarda varlıklarını sürdürmeleri ile birlikte rekabet avantajını ellerinde bulundurmalarını sağlayacak hem de yeşil performansın artırılmasıyla aynı paralellikte kar marjının da artış gösterdiği önemli bir yönetim felsefesi olarak benimsenecektir..

Özellikle Türkiye' de yeşil tedarik zinciri yönetimine ilişkin faaliyetler son zamanlarda çeşitli sektörlerde hız kazanmış olsa da ilgili literatür incelendiğinde sağllk sektöründe yeşil tedarik zinciri yönetimi konusunda kısıtlı oranda çalışmaya ulaşılmıştır. Bu durum da; ülkemiz sağlık sektöründeki yeşil tedarik zinciri yönetimine sağlık çalışanları gözünden bakmayı amaçlayan bu çalışmanın yapılmasına zemin hazırlamıştır.

Çalışma sonucunda; yeşil tedarik zinciri yönetiminin alt boyutlarından yeşil tersine lojistik konusunda erkek katılımcıların bilgi düzeylerinin daha yüksek olduğu, bununla birlikte medeni durumu bekar olan katılımcıların da aynı şekilde yeşil tersine lojistik konusundaki bilgi düzeylerinin daha yüksek olduğu tespit 


\section{E. A. Atilla - F. Seyhan 13/3 (2021) 2488-2506}

edilmiştir. Ayrıca 25 yaş altı katılımcılar ile 35-41 yaş arası katılımcıların yeşil tedarik, yeşil paketleme, yeşil taşıma, yeşil depolama ve yeşil tersine lojistik faaliyetleri hakkındaki bilgi düzeylerinin diğer katılımcılara göre daha yüksek olduğu tespit edilmiş olup bahse konu bilgi düzeyinin yüksek olmasının nedeninin özellikle 25 yaş altı katılımcılarda mezuniyet sonrası yeşil tedarik zinciri yönetimi konusunda güncel bilgilere sahip olmalarından kaynaklandığı değerlendirilmektedir. Bununla birlikte 2-8 yıl arası kurumda çalışma sürelerine sahip katılımcıların alt boyutlardan yeşil tedarik, yeşil üretim ve malzeme yönetimi, yeşil paketleme, yeşil depolama, yeşil tersine lojistik faaliyetleri hakkında bilgi düzeylerinin diğer gruplara göre daha yüksek olduğu, bunun nedeninin daha önce ifade edildiği üzere mesleğe yakın zamanda başlamış olan çalışanların yeşil tedarik zinciri yönetimi konusundaki güncel bilgilerden kaynaklandığı, 16 yıl ve üzeri çalışan grubun diğer gruplara göre daha düşük bilgi düzeyine sahip olmasının nedeninin ise bahse konu gruptaki katılımcların artan hizmet süresi ile birlikte yeşil tedarik zinciri yönetimi konusunda güncel bilgileri takip etme isteklerindeki düşüş ve bununla birlikte değişime karşı direnç unsurundan kaynaklandığı değerlendirilmektedir. Çalışmadan elde edilen başka bir sonuç ise idari birimlerde görev yapan katılımcıların yeşil üretim ve malzeme yönetimi boyutu hakkında bilgi düzeylerinin yüksek olduğu, bunun nedeninin ise sağlık kurumlarında özellikle idari birim sorumlularının kuruma tedarik edilecek malzemelerin üretiminden nihai kullanıcıya teslimine kadarki tüm süreçlerine katılım gösterdiği ve bunun bir sonucu olarak da yeşil tedarik zinciri yönetimi konusunda gerekli bilgiye sahip olmalarından kaynaklandığı değerlendirilmektedir.

Çabuk ve diğerleri (2008) tarafından tüketicilerin sosyo-demografik özellikleri ile yeşil satın alma davranışları arasındaki ilişkilerin incelemek amacıyla yapılan çalışma sonucunda tüketicilerin yeşil satın alma davranışları ile cinsiyet, medeni durumu, yaş, eğitim düzeyi ve geliri arasında anlamlı ilişkiler bulunmuş iken, tarafımızca yapılmış olan araştırmanın sonuçlarında ise; yeşil satın alma davranışı ile yaş arasında anlamlı ilişki söz konusu olup cinsiyet, medeni durum, gelir düzeyi ve eğitim düzeyi arasında anlamlı ilişki bulunamamıştır.

Güner (2010) tarafından işletmelerin çevresel kriterlere ne derece önem verdiklerini ortaya çıkarmak ve bu doğrultuda hem işletmenin hem de müşterilerin yeşil tedarik zinciri algılarını belirlemek amacıyla yapılmış olan çalışmada çevresel faktörlerin hem işletme açısından hem de müşteriler açısından öncelikli konumda olmadığı sonucuna varılmış olup, tarafımızca yapılmış olan araştırmanın sonuçlarını destekler niteliktedir.

Güner ve Coşkun (2013) tarafından işletmelerin çevresel algılarını belirlemek ve müşterilerinin çevrecilik hakkındaki tutum ve görüşlerini ortaya koymak amacıyla yapılan çalışmanın sonucunda işletmelerin çevresel duyarlılık konusunda yeterli bilgiye sahip olmadıkları ortaya konulmuş olup tarafımızca yapılmış olan araştırmanın sonuçlarını destekler niteliktedir.

Gemlik ve diğerleri (2019) tarafından yeşil hastanelerde görev yapan hastane yöneticilerinin yeşil hastane farkındalığını ölçmek amacıyla yapılmış nitel araştırma sonucunda; teknik birim yöneticilerinin yaptıkları işle ilgili olmasından dolayı yeşil hastane konseptine hakim olduğu ancak diğer yöneticiler için aynı durumun söz konusu olmadığı özetle yeşil hastane yöneticilerinin farkındalığının yeterli olmadığı saptanmış olup tarafımızca yapılmış olan araştırmanın sonuçlarını destekler niteliktedir.

Görücü (2019) tarafından hastanelerde yeşil tedarik zinciri konusunda mevcut farkındalığı keşfetmek ve malzeme satın alımından nihai olarak geri dönüşüm ve bertarafına kadar olan süreçten oluşan yeşil tedarik zinciri uygulamalarının hastanelere olan etkilerini ortaya koymak amacıyla yapılmış olan nitel araştırma sonucunda, personelin yeşil tedarik zinciri ve yeşil uygulamalar konusunda yeterli bilgi düzeyine sahip olmadığı ve çevre bilincinin söz konusu olmadığı tespit edilmiş olup tarafımızca yapılmış olan araştırmanın sonuçlarını destekler niteliktedir.

Diğer araştırma bulguları incelendiğinde de hem işletmelerde hem de sağlık kurumlarında gerek yönetim birimlerinin gerekse de görevli personelin yeşil tedarik zinciri yönetimi ve yeşil uygulamalar konusunda bilgi eksikliği söz konusu olduğu görülmüş olup konu hakkında en büyük engellerden birisi olan bilgi eksikliğinin giderilmesi için sağlık kurumlarında görev yapan personelin yeşil ürünler ve uygulamalar konusunda bilinçlendirilmesi ve bu eğitimlerin sürekliliğinin sağlanması gerekmektedir.

Sağlık kurumlarını yeşil uygulamalara yönlendiren itici unsurların yalnızca ekonomik kaygılar veya da yasal zorunluluklar olmaması gerektiği, gerek kurumun gerekse de hastaların kıt kaynaklardan yararlandığı doğal çevresine karşı da sorumlu olarak faaliyetlerine ve yaşamlarına devam etmeleri gerektiği düşünülmekte olup 


\section{E. A. Atilla - F. Seyhan 13/3 (2021) 2488-2506}

bu doğrultuda sağlık kurumlarının yeşil tedarik zinciri faaliyetlerine önem vererek yeşil girişimlerde bulunması büyük önem arz etmektedir.

Gerek politika yapıcı ve karar vericiler gerekse de sağlık kurumları yöneticileri yeşil tedarik zinciri faaliyetlerinin getireceği maliyetlerden ziyade ileriye yönelik düşünüldüğünde getireceği ekonomik ve ekolojik faydaları göz önünde bulundurularak sürdürmüş oldukları satın alma, üretim ve malzeme yönetimi, ambalajlama, taşıma, depolama ve tersine lojistik faaliyetlerini yeşil uygulamalarla revize etmeli ayrıca atık yönetimi politikalarını da bu doğrultuda güncellemelidir.

Yukarıda elde edilen bulgular ışığında bu çalışma, gerek sağlık kurumlarında gerekse de diğer sektörlerdeki yeşil tedarik zinciri literatürüne katkıda bulunmasının yanı sıra araştırmacılara da sağlık kurumlarında yeşil tedarik zinciri uygulamalarında hangi aşamada olunduğunun ve neler yapılması gerektiğinin, bununla birlikte sağlık kurumlarında çalışanların yeşil tedarik zinciri farkındalıklarının ve duyarlılıklarının arttırılmasına yönelik ipuçlarını vermesi açısından katkıda bulunacağı düşünülmektedir. Ayrıca makro düzeyde sağlık sistemi karar verici ve aktörleri mikro düzeyde ise sağlık kurumları yöneticileri ve birim sorumluları tarafından, çalışanlarına yeşil tedarik zinciri yönetimi ve faaliyetleri hakkında eğitim vermek suretiyle bilinçlendirmesi, zincirin tüm paydaşları arasında verilen eğitimler ve yeşil uygulamalar doğrultusunda proaktif bir iletişimin sağlanması ve böylece sağlık kurumlarında çalışan personelin yeşil uygulamalara uyum sağlayıp değişime adapte olabilmeleri açısından büyük önem arz ettiği de değerlendirilmektedir.

\section{Kaynakça}

Alkaya, A., Çoban, S., Tehci, A. \& Ersoy, Y. (2016). “Çevresel duyarlılığın yeşil ürün satın alma davranışına etkisi: Ordu Üniversitesi örneği", Erciyes Üniversitesi İktisadi ve İdari Bilimler Fakültesi Dergisi, Sayı: 47, Ocak-Haziran 2016 ss. 121-134

Bachok, S., Khuzzan, S.M.S., Jaafar, S. \& Baharudin, H. (2004) ‘Construction supply chain management and coordinated design drawings: an outlook of the construction industry and sustainable urban planning' In: 9th International Symposition on Planning \& IT, Vienna, Februray, pp. 67-84.

Bhakoo V. \& Chan C. (2011). Collaborative implementation of e-business processes within the health-care supply chain. supply chain management: An International Journal, 16(3), 184-193.

Büyüközkan, G. \& Vardaloğlu, Z. (2008). "Yeşil tedarik zinciri yönetimi". Lojistik Dergisi, 8, 66- 73.

Cervera, C.M. \& Flores, J.L.M. (2012). A conceptual model for a green supply chain strategy, Global Conference on Business and Finance Proceedings, 7(2), 269-273.

Cramer J. (1996). "Experiences with implementing integrated chain management in Dutch industry", Business Strategy And The Environment, 4 (1), 38-47.

Çabuk, S., Nakıboğlu, B. \& Keleş, C. (2008). Tüketicilerin yeşil (ürün) satın alma davranışlarının sosyodemografik değişkenler açısından incelenmesi, Çukurova Üniversitesi Sosyal Bilimler Enstitüsü Dergisi, Cilt 17, Sayı 1, s.85-102.

Dheeraj, N. \& Vishal, N. (2012). An overview of green supply chain management in India, Res. J. Recent Sci., Volume 1, Issue (6), Pages 77-82, June,2.

Gemlik, N., Arslanoğlu, A., Gün, M. \& Aslan, Ü. (2019). Hastane yöneticilerinin yeşil hastane farkındalığı üzerine nitel bir araştırma, Uluslararası Sosyal ve Beşeri Bilimler Araştırma Dergisi, Cilt:6 Sayı:40 ss:2135-2144.

Görücü, M. (2019). Bir sağlık işletmesinde yeşil tedarik zinciri yönetimi süreçlerinin değerlendirilmesi, Pamukkale Üniversitesi Sosyal Bilimler Enstitüsü, Yayınlanmış Yüksek Lisans Tezi, Denizli.

Güner, S. (2010). Kobilerde yeşil tedarik zinciri algılaması: Sakarya bölgesi uygulaması, Sakarya Üniversitesi Sosyal Bilimler Enstitüsü, Yayınlanmış Yüksek Lisans Tezi, Sakarya.

Güner, S. \& Coşkun, E. (2013). Küçük ve orta ölçekli işletmelerin çevre algıları ve alıcı-tedarikçi ilişkilerinin çevreci uygulamalar üzerindeki etkisi, Ege Akademik Bakış, Cilt: 13, Sayı: 2, ss. 151-167. 


\section{E. A. Atilla - F. Seyhan 13/3 (2021) 2488-2506}

Hervani, A.A., Helms, M.M. \& Sarkis J. (2005). "Performance measurement for green supply chain management", Benchmarking: An International Journal, 12(4), 330-353.

Ho, J. C., Shalishali, M. K., Tseng, T., \& Ang, D. S. (2009). Opportunities in green supply chain management. The Coastal Business Journal, 8(1), 18-31.

Kaitelidou, D., Kontogianni, A., Galanis, P., Siskou, O., Mallidou, A., Pavlakis, A., ... Liaropoulos, L. (2011). Conflict management and job satisfaction in paediatric hospitals in Greece. Journal of Nursing Management, 20(4), 571-578. doi:10.1111/j.1365-2834.2011.01196.x.

Korucuk, S. (2018). “Yeşil lojistik uygulamalarının rekabet gücü ve hastane performansına etkisinin lojistik regresyon analizi ile belirlenmesi: Ankara ili örneği", C.Ü. İktisadi ve İdari Bilimler Dergisi, Cilt 19, Say1 1.

Lee, H.L., \& Billington C. (1992). Managing supply chain inventory: pitfalls and opportunities. Sloane Management Review, 33 (3), 65-73.

Min, H. \& Kim, I. (2012). Green supply chain research: past, present, and Future, Logist. Res., 4, 39-47.

Mishra, P. \& Kumar Sharma, R. (2015). Integration of Six Sigma and ISM to improve Supply Chain Coordination: A conceptual framework, International Journal of Production Management, 3(1), 75-85.

Newbold, P., 1995. Statistics for business and economics. Prentice-Hall International, New Jersey, pp.867.

Oral, M. (2009). Green supply chain management research: ontological and epistemological issues. (Rapport No: 2009-57). s.1-10, Montreal, Kanada: Cirrelt.

Özkan, O., Bayın, G. \& Yeşilaydın, G. (2015). "Sağlık Sektöründe Yalın Tedarik Zinciri Yönetimi" AJITe:Online, Academic Journal of Information Technology, Cilt/Vol:6- Say1/Num:18,DOI:10.5824/13091581.2015.1.005.x, s.71-94.

Seman, N., Abu, A., Zakuan, N., Jusoh, A., Arif, M.S. \& Saman, M.Z. (2012). Green supply chain management: a review and research direction, International Journal of Managing Value and Supply Chains, 3(1), 1-18.

Seuring, S. (2004). Industrial ecology, life cycles, supply chains: differences and interrelations, Business Strategy $\mathcal{E}$ The Environment, 13(5), 306-19.

Shamdasani, P., Chon-Lin, G.O., \& Richmond, D. (1993). “Exploring green consumers in an oriental culture: Role of personal and marketing mix factors", Advances in Consumer Research, 20, 488-493.

Srivastava, S. K. (2007), “Green supply-chain management: a state-of-the-art literature review”. International Journal Of Management Reviews, 9(1),53-80.

Srivastava, S.K. (2008). Network Design for Reverse Lojistics, , Omega International Journal of Reviews, 36, 4, 535548.

Tengilimoğlu D., Işık, O. \& Akbolat M. (2009); Sağlık işletmeleri yönetimi, Nobel Yayın Dağıtım, 1. Baskıı, Ankara ss.71-204.

Tengilimoğlu D. \& Yiğit V. (2017) Sağllk işletmelerinde tedarik zinciri ve malzeme yönetimi, Nobel Akademik Yayıncllık, Ankara.

Terekli, G., Özkan, O. \& Bayın, G. (2013). "Çevre dostu hastaneler: hastaneden yeşil hastaneye”, Sağlık Hizmetleri Dergisi, 12 (2): 37, Ankara.

Toke, L.K., Gupta, R.C. \& Dandekar, M. (2010). Green supply chain management: Critical research and practices. Proceedings of the 2010 International Conference on Industrial Engineering and Operations Management, S. 1-7., 9-10 Ocak 2010, Dakka, Bangladeş.

Veber, J. \& Wallenburg, C.M. (2010), 'Logistik und supply chain controlling', Stuttgart, Schaffer-Poeschelverlag.

Walker, H. Sisto L.D., \& McBain, D., (2008) "Drivers and barriers to environmental supply chain management practices: Lessons from the public and private sectors", Journal of Purchasing $\mathcal{E}$ Supply Management, 14, pp. 69-85. 


\section{E. A. Atilla - F. Seyhan 13/3 (2021) 2488-2506}

Yaşlığlu, M.M. (2017). Sosyal Bilimlerde faktör analizi ve geçerlilik: Keşfedici ve doğrulayıcı faktör analizlerinin kullanılması, İstanbul Üniversitesi İşletme Fakültesi Dergisi, Cilt: 46, Özel Sayı 2017, 74-85.

Zhu, Q. \& Sarkis, J. (2004). Relationships between operational practices and performance among early adopters of green supply chain management practices in Chinese manufacturing enterprises, Journal of Operations Management, 22, 265-289

Zhu, Q., Sarkis J. \& Geng Y., (2005)"Green supply chain management in China: pressures, practices and performance", International Journal of Operations EProduction Management, Vol. 25 No. 5, pp. 449-468.

Zhu, Q. \& Sarkis, J. (2006). An inter-sectoral comparison of green supply chain management in China: Drivers and practices, Journal of Cleaner Production, 14, pp. 472- 486.

Zhu, Q. \& Sarkis J. (2007). The moderating effects of institutional pressures on emergent green supply chain practices and performance, International Journal of Production Research, 45, 4333-4355.

Zhu, Q., Sarkis, J., Cordeiro, J. \& Lai, K.L.,(2008) Firm-level correlates of emergent green supply chain management practices in the Chinese context, The international journal of management science Omega,36 ,pp.577- 591 .

Zhu, Q., Lai, K. \& Sarkis, J. (2008). Green supply chain management implications for "closing the loop". Transportation Research Part E: Logistics and Transportation Review, 44(1), 1-18. 